\title{
Aminoacyl-analogues of Mitoxantrone as novel DNA-damaging cytotoxic agents
}

\author{
Giuseppe Zagotto, Claudia Sissi, Barbara Gatto, and Manlio Palumbo* \\ Department of Pharmaceutical Sciences, University of Padova, \\ Via Marzolo 5, 35131 Padova (Italy) \\ E-mail: manlio.palumbo@unipd.it
}

In honour of Professor Vincenzo Tortorella in the occasion of his "Fuori Ruolo" status

(received 20 Dec 03; accepted 17 Mar 04; published on the web 19 Mar 04)

\begin{abstract}
Anthracenedione derivatives are widely used structures to target DNA in chemotherapy. One of the major problem related to their use is their lack of sequence selectivity along the genome. With the aim of favoring recognition of selected DNA sequences, we synthesized four novel aminoacyl derivatives. Two side chains carrying aminoacid residues different for charge and chirality have been introduced at positions 1 and 4 of 5,8-dihydroxyanthracene-9,10-dione. An aminoethylamino spacer was inserted between the planar ring system and the selected aminoacid residues. Investigations in DNA binding properties of these new derivatives showed a large modulation of the drugs affinities for the nucleic acid depending upon the charge of the aminoacid used but irrespective of its chirality. However, as shown by topoisomerase II poisoning, prominent DNA-binding properties did not grant superior topoisomerase inhibition due mainly to template effect. In turn, aminoacid chirality plays a critical role in the in vitro cytotoxicity, L enantiomers being much more effective than $\mathrm{D}$ enantiomers. These findings suggest that conjugation of the anthracenedione moiety to aminoacids/peptides can be a valuable tool to selectively target cancer cells.
\end{abstract}

Keywords: Aminoacyl anthraquinones, DNA-binder, sequence-specificity, chirality, topoisomerase II

\section{Introduction}

One of the major problems in cancer chemotherapy is the presence of prominent side effects. ${ }^{1-3}$ Often, this problem is linked to a poor selectivity for a unique target. In particular, for DNAdamaging agents a issue of great relevance is represented by lack of sequence selectivity along the genome. An approach to overcome this drawback, leading to a generalized toxicity, is to 
include into the drug chemical functions aimed at recognizing appropriate DNA sequences. Were this the case, it would be possible to damage mutated DNA sequences (i. e. oncogenes) only, while preserving normal DNA from drug action. Reaching this goal is a very hard task. Small molecules cannot per se span a sufficient length of a DNA chain to unambiguously recognize just one site along the whole genome. Hence, drug conjugates with appropriate nucleic-acid tethering groups must be considered to increase selective recognition. Targeting elements recently used in combination with drugs cleaving DNA through a topoisomerase-mediated process include specific groove-binder structures such as the antibiotics netropsin and distamycin, ${ }^{4}$ hairpin pyrrole-imidazole polyamides ${ }^{5,6}$ and triplex-forming oligonucleotides. ${ }^{7,8}$ In the first two examples, the resulting compounds are tethered to the minor groove, while major groove binding is expected in the third case. The AT-binder conjugates with camptothecin proved to be not very effective, due to their limited sequence-recognition properties. ${ }^{9}$ Nevertheless, drug-polyamide conjugates were found to be able to recruit topoisomerase I to produce specific DNA cleavage. ${ }^{10}$ Other topoisomerase poisons were covalently attached to triple helix-forming oligonucleotides. Besides increasing the drug affinity for DNA, the conjugates were shown to stimulate DNA cleavage in a triplex-directed sequence-specific manner ${ }^{11}$. Nucleic acid recognition in living systems, besides by complementary nucleotide sequences, is generally regulated by interactions with amino-acids belonging to nucleic acid processing proteins. Starting from this natural model, we believe that peptide-drug conjugates could be profitably exploited to obtain novel more specific anticancer agents.

Along this line, we previously investigated the DNA binding properties of anthraquinones linked to one, two or three amino acid residues. ${ }^{12,13}$ These compounds are closely related to mitoxantrone (Mx), a well known topoisomerase poison. ${ }^{14}$ Indeed, the presence of an extended planar ring system along with positively charged side chains rendered Mx an extremely efficient DNA-binder. In addition, the drug efficiently poisoned the topoisomerase II- DNA cleavage complex, preventing the enzyme from resealing the cut DNA intermediate. Among these peptidyl-anthraquinones, the cytotoxic profile was well related to topoisomerase II poisoning, confirming that conjugation did not substantially affect the mechanism of action.

These results were supported by the synthesis and investigation of anthracenyl-amino acid conjugates. ${ }^{15-19}$ They were also shown to act by inhibiting topoisomerases I and II and appeared as promising new drugs. However, all of the previous compounds were lacking the hydroxyl groups in the aromatic planar system, characteristic of $\mathrm{Mx}$ and known to improve drug activity to a substantial extent. ${ }^{20}$ Moreover, in our previous work the amino acidic chains were linked to the anthraquinone moiety through an amide bond which is not so flexible as the amino bond present in Mx. With the aim to improve the pharmacological profile of the conjugate derivatives and to further assess the effects of the above structural modifications in prompting specific DNA recognition, in the present work we synthesized the novel enantiomerically pure aminoacyl derivatives shown in Scheme 1. They were investigated in terms of their DNA binding affinity and specificity, topoisomerase poisoning and cytotoxic properties. Particular attention has been devoted to elucidate the role played by chirality in the structure-activity relationships. 


\section{Results}

\section{Chemistry}

1,4-bis[(2-Aminoethyl)amino]-5,8-dihydroxyanthracene-9,10-dione bis(trifluoroacetate) (1) was obtained from the commercially available 4,8-diamino-1,5-dihydroxyantracene-9,10-dione-2,6disulfonic acid (Acid Blue 45) by procedures already described. ${ }^{21}$ This intermediate was then reacted with L- and R- Boc-Val-OSu or L- and R- Fmoc-Lys(Boc)-OSu to give the protected aminoacid derivatives 2 and 3 that were deprotected to give the final compounds $\mathbf{4}$ (L,D-VAQ) and 5 (L,D-KAQ). All the compounds were characterized by elemental analysis, NMR and mass spectra, chiroptical methods were used to check the absence of racemization within the experimental error.

The aminoethylamino spacer was inserted to allow some degree of freedom for the positioning of the side arms in the most favorable orientation inside the DNA groove. In fact, aminoacyl residues linked directly to the anthracene-9,10-dione nucleus had shown an unfavorable effect in the DNA. ${ }^{22}$ Fmoc-Lys(Boc)-OSu was used instead of a Lys bearing the same protecting group in both $\alpha$ and $\varepsilon$ positions to allow further lengthening of the peptide side chain at both positions. The reaction scheme is shown below:

2

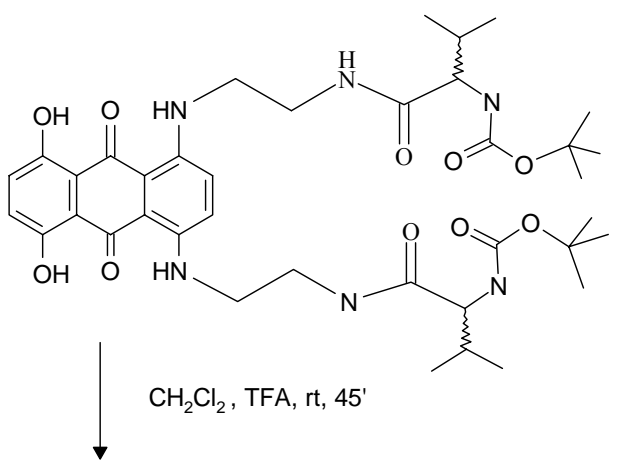

4

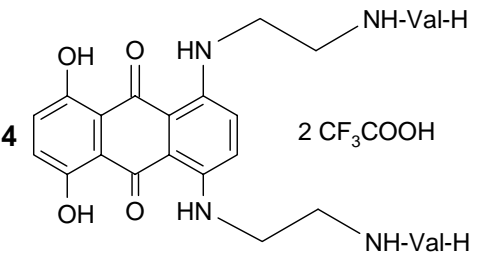

L- or D- VAQ
1
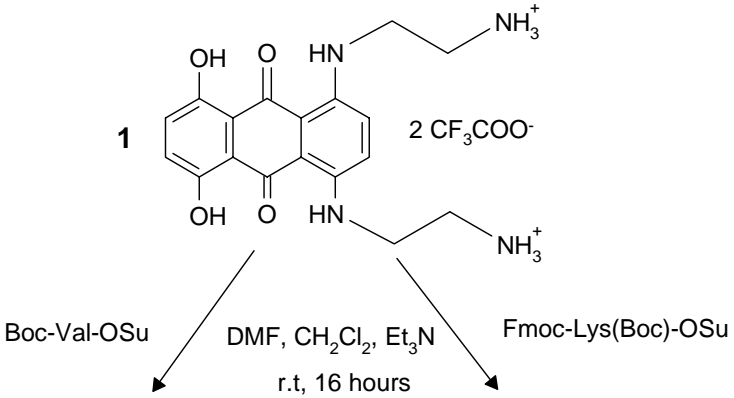

r.t, 16 hours

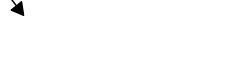

3

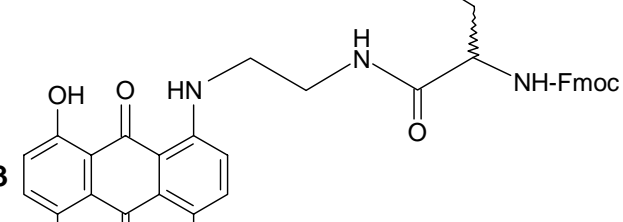

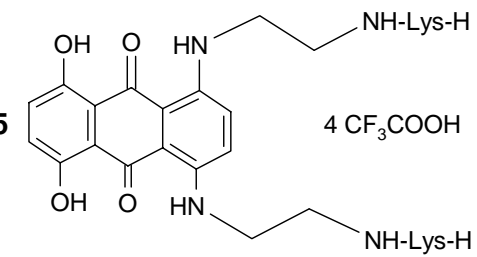

L- or D- KAQ

\section{Scheme 1}




\section{Spectroscopic characterization of the test drugs}

Due to their extended planar ring system, anthracenediones may undergo self-aggregation equilibria in water solution. The absorption spectra are very similar for all the test compounds, as they exhibit two bands in the visible region, located at 615 and $666 \mathrm{~nm}$. When recorded at increasing drug concentrations, they show almost constant absorbance ratios at different wavelengths and no significant deviation from the Beer-Lambert law. These data rule out the presence of significant multimerization processes.

As expected, the extinction values of $\mathrm{L}$ - and $\mathrm{D}$ - isomers were the same within the experimental error $\left(\varepsilon_{615}=11200\right.$ and $11300 \mathrm{M}^{-1} \mathrm{~cm}^{-1}$ for Lys and Val derivatives respectively). Their opposite stereochemistry was confirmed by CD spectroscopy. It is worth noting that compound bearing a Val residue in the side chain exhibits a higher molar ellipticity value $([\theta]=$ $\left.5,000 \mathrm{deg} * \mathrm{~cm}^{*} \mathrm{dmol}^{-1}\right)$ compared to the Lys derivatives $\left([\theta]=1,500 \mathrm{deg} * \mathrm{~cm}^{*} \mathrm{dmol}^{-1}\right)$.

\section{DNA-binding}

The affinity of test anthracenedione conjugates for double stranded DNA was quantitatively evaluated using spectrophotometric techniques.

With all peptidyl-anthraquinones, addition of the nucleic acid to a drug solution produced major spectroscopic changes, in particular a bathochromic and hypochromic shift (Figure 1). Three isosbestic points were always observed. Following the absorbance modification at $666 \mathrm{~nm}$ induced by each addition of DNA, the amount of free and DNA-bound drug could be calculated. An analysis of the binding data at different ionic strength yielded the thermodynamic parameters summarized in Table 1. All derivatives showed no cooperativity in the binding process. Additionally the exclusion parameter, $\mathrm{n}$, was always close to 2 base-pairs supporting an intercalation binding mode.

All test conjugates bind to DNA rather efficiently. In fact, working at ionic strength values comparable to physiological conditions $(0.15 \mathrm{M})$, or even higher, $\mathrm{K}_{\mathrm{i}}$ are always in the $10^{4}-10^{6} \mathrm{M}^{-1}$ range. Dand L- derivatives showed no significant differences in their binding properties, which points to a poor chiral discrimination in the DNA complex.

On the contrary, a remarkable modulation of the DNA binding parameters is observed when changing the aminoacid in the side chains. Indeed, at $0.15 \mathrm{M}$ salt the Lys (KAQ) derivatives bind to DNA 40to 50-fold more efficiently than the Val congeners (VAQ), Mx showing an intermediate affinity.

To evaluate the number of ionic contacts that each anthraquinone molecule forms with the polyanionic DNA chain and the electrostatic contribution to the binding process, the intrinsic binding constant was calculated at different salt concentrations. The slope of the Log Ki vs. $\log$ I.S. plot indicates that VAQs (and Mx) are able to form two ionic pairs with the nucleic acid chain, whereas KAQs possess an additional charged (side chain) moiety per amino-acid residue, which leads to the formation of two additional ionic pairs, further stabilizing the anthraquinoneDNA complex. 


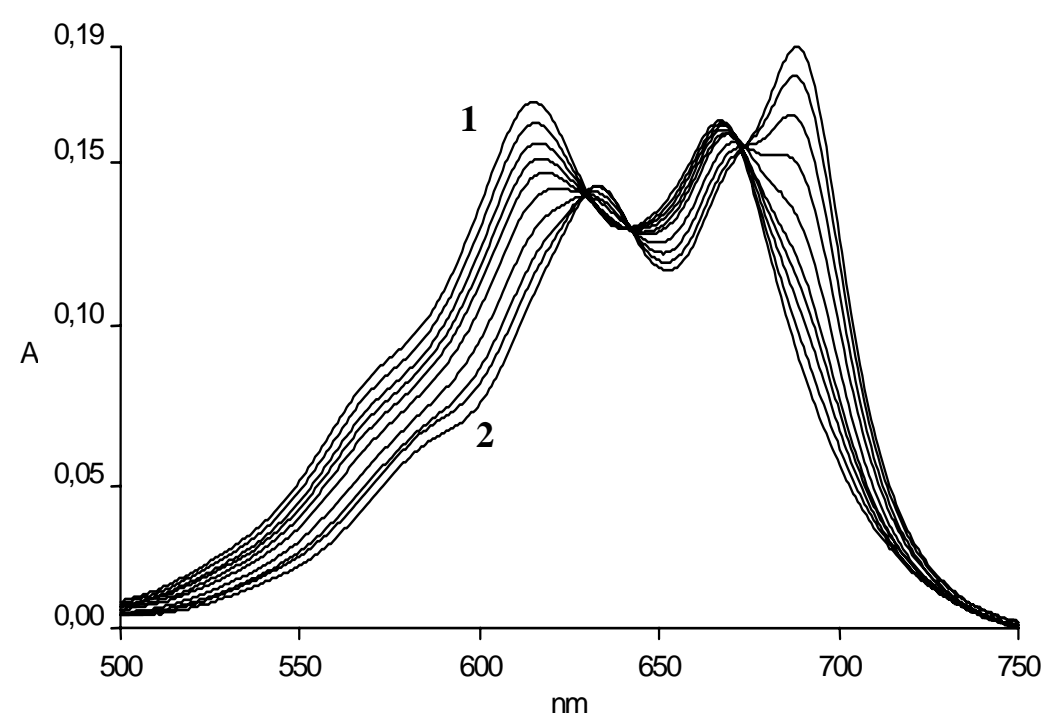

Figure 1. Modifications of the absorption spectra of the L-VAQ derivative in the presence of increasing amounts of ctDNA. 1) free drug; 2) DNA-bound drug. Drug concentrations were $17 \mu$ M. Measurements were performed in ETN buffer $0.25 \mathrm{M}, \mathrm{pH} 7.0$ and $25^{\circ} \mathrm{C}$.

Table 1. Thermodynamic DNA binding properties of the test compounds to ctDNA in ETN buffer at different ionic strength, $\mathrm{pH}=7.0,25^{\circ} \mathrm{C}$

\begin{tabular}{lcccc}
\hline Compound & I.S. $^{\mathrm{a}}(\mathrm{M})$ & $K_{i} \times 10^{-5}\left(\mathrm{M}^{-1}\right)^{\mathrm{b}}$ & $\mathrm{m}^{\mathrm{c}}$ & $-\Delta G^{\mathrm{c}}(\mathrm{kJ} / \mathrm{mol})^{\mathrm{d}}$ \\
& 0.15 & $67 \pm 4.6$ & & \\
L-KAQ & 0.50 & $0.86 \pm 0.04$ & & \\
& 0.75 & $0.17 \pm 0.01$ & 3.8 & $22.3 \pm 1.0$ \\
& 1.00 & $0.08 \pm 0.01$ & & \\
& 0.15 & $74 \pm 4.8$ & & \\
D-KAQ & 0.50 & $0.95 \pm 0.06$ & & \\
& 0.75 & $0.18 \pm 0.01$ & 4.1 & $22.0 \pm 0.9$ \\
& 1.00 & $0.07 \pm 0.01$ & & \\
L-VAQ & 0.15 & $1.57 \pm 0.16$ & & \\
& 0.50 & $0.72 \pm 0.04$ & 2.2 & $21.5 \pm 1.0$ \\
D-VAQ & 0.75 & $0.11 \pm 0.01$ & & \\
& 0.15 & $1.58 \pm 0.15$ & & \\
MX & 0.50 & $0.50 \pm 0.03$ & 2.1 & $20.5 \pm 1.1$ \\
\hline
\end{tabular}

${ }^{\mathrm{a}}$ Ionic strength. ${ }^{\mathrm{b}}$ Intrinsic binding constant. ${ }^{\mathrm{c}}$ Number of ionic pairs formed per complex unit, calculated from the slope of the plot $\log \left(\mathrm{K}_{\mathrm{i}}\right) / \log$ (I.S.). ${ }^{\mathrm{d}}$ Binding free energy corrected for ionic contributions. 
The non-electrostatic binding free energy change observed for the various compounds is in the range -21 to $-22 \mathrm{~kJ} / \mathrm{mol}$, whereas for $\mathrm{Mx}$ it is almost $-30 \mathrm{~kJ} / \mathrm{mol}$.

\section{DNA sequence specificity}

The DNA sequence binding preferences of test derivatives were evaluated by extending thermodynamic studies to Micrococcus Lysodeikticus DNA (Ml DNA, GC content 72\%) and to the synthetic polynucleotides poly $(\mathrm{dA}-\mathrm{dT})$ and poly $(\mathrm{dG}-\mathrm{dC})$. The results of a number of spectroscopic titrations are summarized in Table 2 and compared in Figure 2.

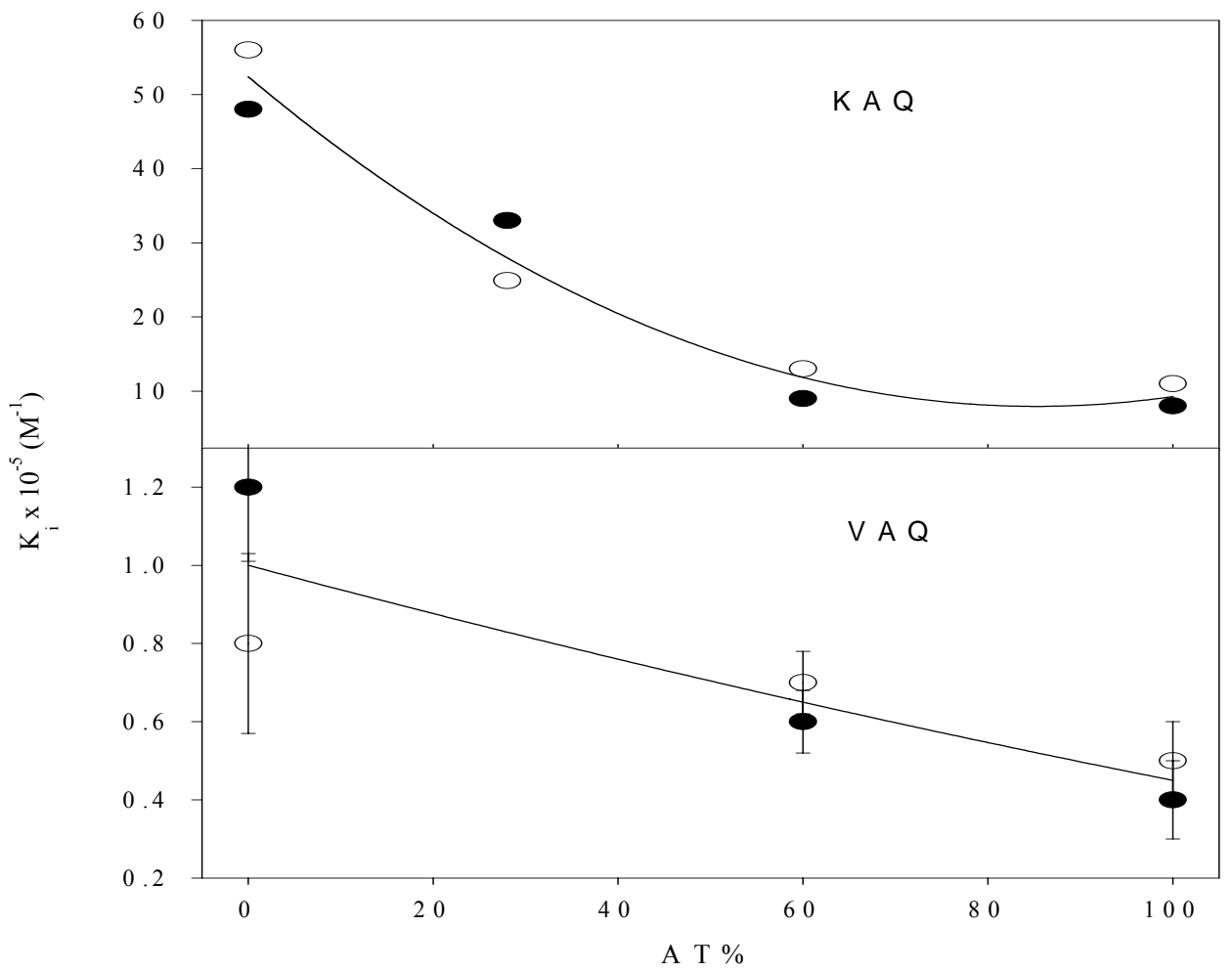

Figure 2. Effects of DNA composition on the binding affinity of test aminoacyl anthraquinones. The binding affinity for each drug has been calculated in ETN buffer, $0.25 \mathrm{M}$ ionic strength, $\mathrm{pH}$ $7.0,25^{\circ} \mathrm{C}$. Open symbols refers to $\mathrm{L}$ isomers, black fill symbols to $\mathrm{D}$ isomers. 
Table 2. Thermodynamic parameters for the binding of the test aminoacyl anthraquinones to nucleic acids having different base-pair composition in ETN buffer, $0.25 \mathrm{M}$ ionic strength, $\mathrm{pH}$ $7.0,25^{\circ} \mathrm{C}$. The exclusion parameter, $\mathrm{n}$, was always close to 2 base-pairs

\begin{tabular}{ccccc}
\hline & \multicolumn{4}{c}{$\mathrm{K}_{\mathrm{i}} \times 10^{-5}\left(\mathrm{M}^{-1}\right)$} \\
\cline { 2 - 5 } Compound & poly $(\mathrm{dA}-\mathrm{dT})$ & ctDNA & Ml DNA & poly $(\mathrm{dG}-\mathrm{dC})$ \\
\hline L-KAQ & $8.01 \pm 0.15$ & $8.95 \pm 0.74$ & $33.3 \pm 0.39$ & $48.01 \pm 0.61$ \\
L-KAQ & $11.4 \pm 0.15$ & $13.0 \pm 0.06$ & $24.9 \pm 0.29$ & $56.31 \pm 0.40$ \\
D-VAQ & $0.55 \pm 0.08$ & $0.72 \pm 0.09$ & n.d. ${ }^{\mathrm{a}}$ & $0.83 \pm 0.23$ \\
\hline
\end{tabular}

${ }^{\mathrm{a}}$ Not determined.

For all test compounds, a preference for GC base pairs is found. The Lys-derivatives are more selective for GC base pairs compared to the Val analogues $\left(\mathrm{K}_{\mathrm{i}, \mathrm{GC}} / \mathrm{K}_{\mathrm{i}, \mathrm{AT}}=6 \mathrm{vs} 3\right)$. Again, the chirality of the amino acids in the side chains seems to play a minor role, as the enantiomers show a closely similar behavior.

\section{Cell cytotoxicity}

The cytotoxic activity of test derivatives was evaluated in the HL60 cancer cell line. Results are presented in Figure 3.

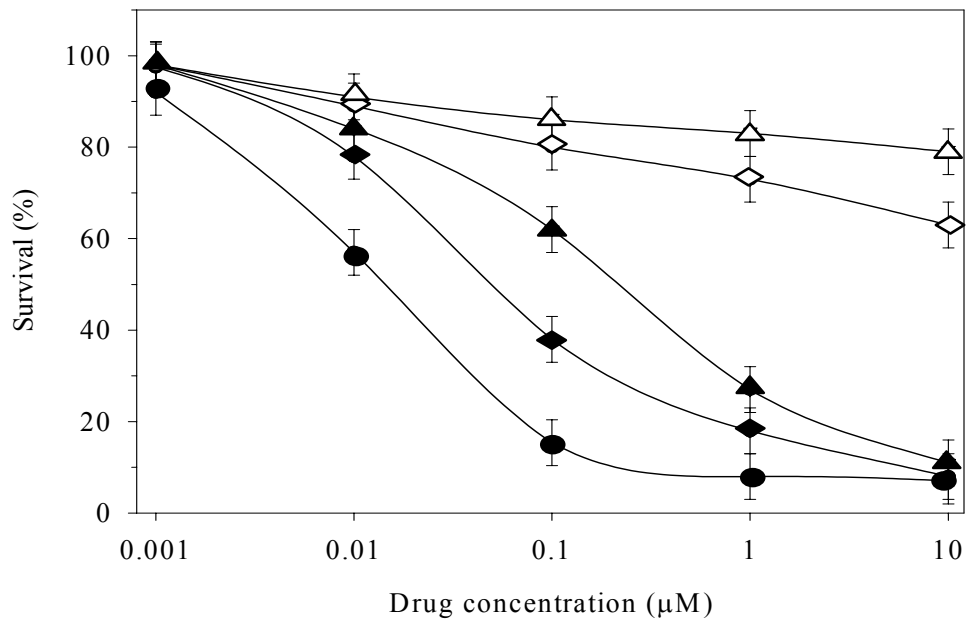

Figure 3. Cytotoxic responses exhibited by test compounds in the HL60 tumor cell line. Symbols: •, Mx; • L-VAQ; • , L-KAQ . Open symbols refer to the corresponding D- isomers. 
Here, a clear discrimination between L- and D- enantiomers is observed, the former being more potent than the latter. Also, Valyl derivatives are more effective than Lysyl derivatives. The $\mathrm{IC}_{50}$ values, in the sub-micromolar range for L-KAQ and L-VAQ, are summarized in Table 3.

Table 3. $\mathrm{IC}_{50}{ }^{\mathrm{a}}$ values of the examined aminoacyl anthraquinones on the HL60 tumor cell line

\begin{tabular}{ll}
\hline Compound & $\mathrm{IC}_{50}(\mu \mathrm{M})^{\mathrm{a}}$ \\
\hline L-KAQ & $0.2 \pm 0.04$ \\
D-KAQ & $>10$ \\
L-VAQ - & $0.05 \pm 0.02$ \\
D-VAQ & $>10$ \\
Mx & $0.02 \pm 0.01$ \\
Ametantrone & $0.9 \pm 0.2$ \\
\hline
\end{tabular}

${ }^{a}$ Drug concentration that inhibits $50 \%$ of cell growth.

\section{Topoisomerase II poisoning}

The ability of test compounds to interfere with Topoisomerase II biological functions was evaluated by determining drug-induced topoisomerase II-mediated DNA cleavage. Results are reported in Figure 4.
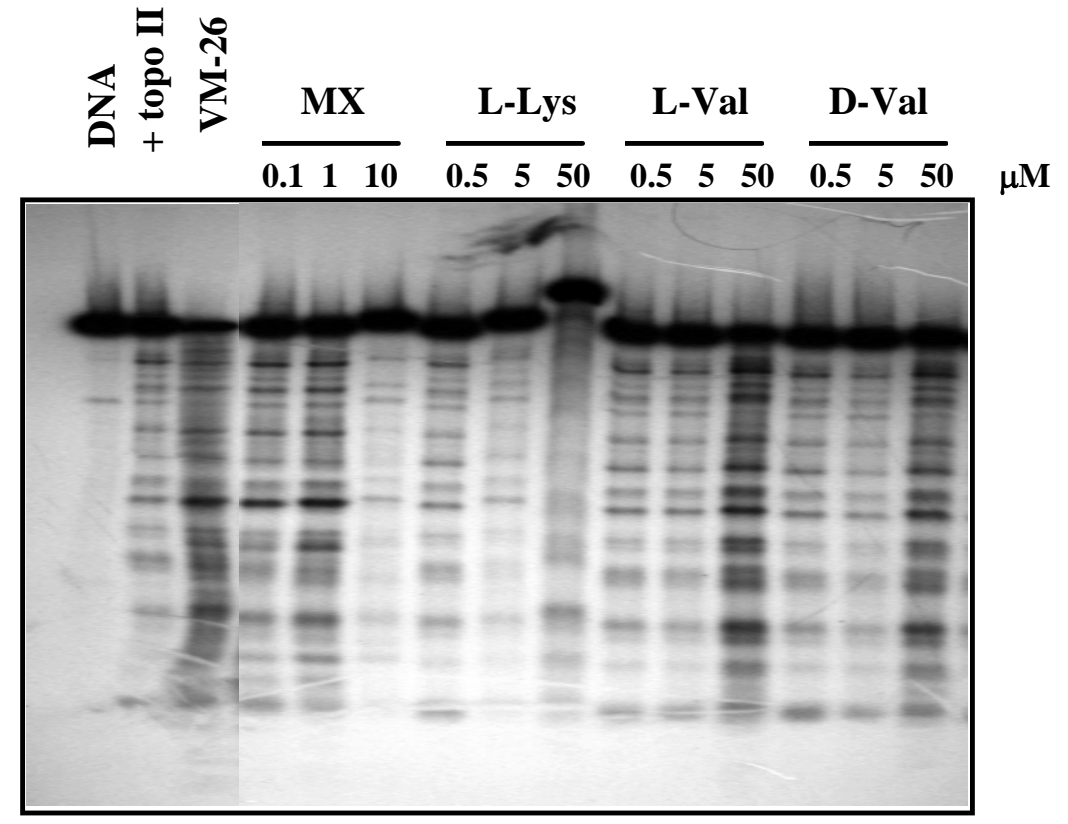

Figure 4. Agarose gel of labelled pBR 322 (50 ng) treated for $30 \mathrm{~min}$ with topoisomerase II in the absence or presence of test compounds at the indicated concentrations. Lane marked (DNA) refers to labelled DNA incubated without drugs or enzyme; lane marked (+ topo II) corresponds to enzyme digestion in the absence of drugs. VM-26 is etoposide and MX mitoxantrone. 
Anthraquinone congeners induce enzyme-mediated cleavage albeit to a lesser extent than Mx. The VAQ- derivatives produce increased stimulation upon increasing drug concentration up to $50 \mu \mathrm{M}$, whereas $\mathrm{Mx}$ and L-KAQ exhibit the classical bell shaped behaviour. Also, in this biochemical assay enantiomeric compounds showed comparable stimulation ability.

\section{Discussion and Conclusions}

The test aminoacyl anthraquinones can be considered as $\mathrm{Mx}$ congeners in which the hydroxyethyl groups of the side chains in the reference drug have been replaced by an amino acid residue in either the $\mathrm{L}$ or $\mathrm{D}$ configuration. We have examined two representative examples of polar (lysyl, KAQ) and apolar (valyl, VAQ) side chain. A positively charged side chain as in KAQ was chosen as an example of polar system, as it can be reasonably expected to provide effective interactions with DNA, which is known to represent an important co-target for the Mx family.

Lack of self-aggregation phenomena render the novel compounds simpler to investigate and interesting from a pharmacokinetic point of view. In fact some of the currently used drugs, having the anthracene/anthracenedione structure, easily undergo multimerization equilibria, ${ }^{23}$ which influences both membrane crossing ability, solubility in biological fluids and target recognition.

The DNA-binding studies show a large modulation of the drugs affinities for the nucleic acid. The KAQ compounds are outstanding binders, their intrinsic binding constant being 7-8 fold greater than that for $\mathrm{Mx}$ at physiological salt, which, on turn, is about 6 times higher than that for VAQs. This points to efficient charged interactions between each of the KAQ doubly protonated side-chains and the nucleic acid negative charge density and is confirmed by the $\mathrm{m}$ ' value of 4 found from the dependence of $K_{i}$ upon salt concentration. On the other hand, the lower affinity of the VAQ derivatives must rest on a less efficient interaction of the branched aminoacid residue as compared to the linear hydroxyethyl residue in Mx. This agrees with literature reports suggesting that side-chain branching was reducing activity of the $\mathrm{Mx}$ family. ${ }^{24}$ Evaluation of the non-charged contribution to the binding free energy change gives us further insight into this point as the electrostatic effects are taken apart. All aminoacyl hydroxy anthraquinones give essentially the same value for $\Delta \mathrm{G}^{\circ}$. This suggests a very similar mode of interaction with (intercalation into) DNA with almost identical binding contacts. Interestingly, Mx binds more efficiently though non-electrostatic bonding. The only explanation that can account for these findings is that the side-chain hydroxyl groups of Mx participate in hydrogen bonding to DNA while aminoacyl terminal residues in the new compounds do not. In fact, the importance of side-chain $\mathrm{OH}$ groups in improving the activity of $\mathrm{Mx}$ is well known, ${ }^{20}$ the replacement with amino residues leading to less effective compounds. ${ }^{25}$ The DNA-binding affinity for KAQs increases 6-fold when using poly(dG-dC) instead of poly(dA-dT), whereas this preference is reduced to a factor of 2-3 in the VAQ series. For Mx a preference factor of 
about 3 has been reported. ${ }^{26}$ It is not immediately evident why the more charged derivative should exhibit higher base selectivity. It is however worth recalling that $\mathrm{Mx}$ is proposed to intercalate into CG base pairs with the side chains located in the major groove of duplex DNA. ${ }^{27}$ Interestingly, the deepest electrostatic potential minimum in a double-helical structure is located in the major groove for a CG step. ${ }^{28}$ Hence the KAQ derivatives would place four positively charged groups at a location where charge density is highly negative and thus substantially preferred. In this case, the extra charges exhibited by KAQ in comparison to Mx and VAQ should be responsible for increased sequence preference. In agreement with the above findings, other anthraquinone conjugates previously investigated showed remarkable GC specificity for lysyl containing-derivatives. ${ }^{13}$

The prominent DNA-binding properties, however, do not grant superior topoisomerase inhibition.

Indeed, topoisomerase II poisoning activity is overwhelmed by template occupancy by KAQs, so that we observe inhibition, rather than stimulation of DNA cleavage, at least at drug concentrations above $0.5 \mu \mathrm{M}$. On the other hand, the poorer binders VAQs do stimulate enzymemediated damage of the nucleic acid in a concentration-dependent fashion. Hence, the likely mechanism through which the drugs cause cell death has to be related to topoisomerase poisoning.

Interestingly enough and unlike the previously examined lysyl-anthraquinones, drug chirality does not appear to play a discriminating role either for KAQ or for VAQ DNA binding or topoisomerase interference, both enantiomers exhibiting very close $\mathrm{K}_{\mathrm{i}}$ values and very similar stimulation patterns of enzyme-mediated DNA breaks. This is possibly explained by the increased flexibility of the side chains containing the chiral center in the novel compounds. Indeed, in the previous work we dealt with amido-anthraquinones, and the only flexible group between the nitrogen linked to the planar section and the asymmetric $\alpha$ carbon was the glycyl methylene residue. Here, we have two adjacent methylenes, that are probably allowing the rest of the side chain to adopt conformations able to accommodate both $\mathrm{L}$ and $\mathrm{D}$ chiral centers in the DNA or topoisomerase-DNA complex without substantially affecting binding energetics or enzyme recognition.

What is really surprising is the data concerning the cytotoxic potency of the test drugs. Although $\mathrm{Mx}$ is the most potent, the rank of potencies shown by test aminoacyl-anthraquinones is well differentiated. Indeed, the conjugates containing L-amino acids proved to be very effective in tumor cell killing, whereas the corresponding D-analogues were much less active. In addition, the less polar VAQ structure preferentially killed HL60 cells in comparison to KAQ. These very impressive findings can be explained either by a discriminating cytotoxic mechanism not topoisomerase/DNA-related, or by an active cell uptake process, prompted by the presence of the natural amino-acid linked to the hydroxy-anthraquinone ring system. In this connection, no such effects were described for any of the peptidyl-anthracene conjugates thus far described.

These results suggest that L-VAQ, active in the sub-micromolar range, might represent a valuable new lead to approach the highly noxious effects related to multi-drug-resistance, by 
contrasting rapid drug efflux with facilitated influx. Studies in this direction are in progress in our laboratories.

\section{Experimental Section}

General Procedures. ${ }^{1} \mathrm{H}$ NMR were recorded on a Varian Gemini $200(200 \mathrm{MHz})$ or on a Bruker 300 AMX spectrometer. Elemental analyses (CHN) were within $0.40 \%$ of the calculated values and were performed on a Carlo Erba 1016 Elemental Analyser. Optical purities of the amino acid derivatives were determined by a Perkin-Elmer 141 Polarimeter. Circular dichroism (CD) spectra were recorded on a Jasco 710 Spectropolarimeter interfaced with a Jasco 700 data processor. Quartz cells having $10 \mathrm{~mm}$ pathlength were used, and 4-8 scans were accumulated for each measurement. Reagents and solvents were used as purchased without further purification. Silica gel and TLC plates were from Merck.

${ }^{1} \mathrm{H}$ NMR chemical shifts $(\delta)$ are reported in ppm and coupling constants $(\mathrm{J})$ in $\mathrm{Hz}$, and UV frequencies in nm. FT IR spectra were recorded on a Perkin-Elmer System 1760 FTspectrometer using $\mathrm{KBr}$ mulls, frequencies are in $\mathrm{cm}^{-1}$. Melting points were determined by a Gallenkamp apparatus. Mass spectrometry was carried out using $\sim 10^{-5} \mathrm{M}$ final concentration of the intermediate or final compound and an Applied Biosystem Mariner API-TOF mass spectrometer was used.

Mitoxantrone (NSC 301739-NB9) was kindly provided by Wyeth Lederle (Aprilia, Italy). Stock solutions $(1 \mathrm{mg} / \mathrm{ml})$ were prepared in doubly deionized Millipore-filtered water. They were stored at $4{ }^{\circ} \mathrm{C}$ and diluted to the appropriate concentration in the working buffer immediately before use.

Calf thymus DNA (ctDNA, AT\%=60), Micrococcus lysodeikticus DNA (MIDNA, \%AT = 28), poly(dA-dT), and poly (dG-dC) were purchased from Sigma (St. Louis, MO) and were used without further purification. Their concentrations were determined applying the molar extinction coefficients per residue of $6,600,6,900,6,800$ and $8,400 \mathrm{M}^{-1} \mathrm{~cm}^{-1}$ respectively. ${ }^{29,30}$

Natural DNAs solutions were prepared by suspending the lyophilized DNA overnight at $4{ }^{\circ} \mathrm{C}$ in ETN buffer (10 mM TRIS, $1 \mathrm{mM}$ EDTA, $6 \mathrm{mM} \mathrm{NaCl} \mathrm{pH} \mathrm{7.0).} \mathrm{After} \mathrm{one} \mathrm{hour} \mathrm{shaking,} \mathrm{solutions}$ were filtered through $5 \mu \mathrm{m}$ Teflon filters (Millipore) and the ionic strength was adjusted to the desired value with $\mathrm{NaCl}$.

Human DNA Topoisomerase II was from TopoGEN (Columbus, Ohio), pBR 322, simian virus 40 , restriction enzymes and DNA modifying enzymes were from Invitrogen, and used according to the supplier's recommended protocol in the provided activity buffer. All other chemicals were analytical grade reagents, and all solutions were prepared using doubly deionized, Millipore filtered water. ${ }^{32} \mathrm{P}[\gamma] \mathrm{ATP}(6000 \mathrm{Ci} / \mathrm{mmol})$ was from Perkin Elmer Life Sciences. 
L and D 1,4-bis \{2-[(Fmoc-Lys(Boc)] aminoethylamino $\}$ 5,8-dihydroxyanthracene-9,10-dione (3).1,4-bis[(2-aminoethyl)amino]-5,8-dihydroxyanthracene-9,10-dione bis(trifluoroacetate) 1 $(0.250 \mathrm{~g}, 0.43 \mathrm{mmol})$ was dissolved in a mixture of dichloromethane and DMF 95:5. Then the solution was made alkaline with $\mathrm{N}\left(\mathrm{CH}_{2} \mathrm{CH}_{3}\right)_{3}$ to get the primary amines free for the subsequent reaction. Fmoc-(L or D)Lys(Boc)-OSu (0.682 g, $1.3 \mathrm{mmol}, 3$ equival.) was then added and the mixture was stirred overnight at room temperature. The reaction mixture was poured in water and the organic layer was extracted three times with water to eliminate the DMF from the organic phase. The organic layer was then dried over sodium sulphate and evaporated to dryness under reduced pressure. The solid residue was then crystallized from $95 \%$ ethanol to yield the desired products in $21 \%$ yield for the $\mathrm{L}$ isomer and $23 \%$ for the $\mathrm{R}$ isomer.

${ }^{1} \mathrm{H}-\mathrm{NMR}$ in DMSO-d $\mathrm{d}_{6}$ : 13.6 (s, 2H, OH), 10.6 (t, 2H, $6.1 \mathrm{~Hz}, \mathrm{NHarom}$.), 8.2 (t, 2H, $\left.5.9 \mathrm{~Hz}, \mathrm{NH}\right)$, 7.9-7.0 (m, 24H, aromatics+NH), $6.8(\mathrm{t}, 2 \mathrm{H}, 6.4 \mathrm{~Hz}, \mathrm{NH}), 4.2$ (s broad, 4H, $\mathrm{CH}_{2}$ [Fmoc]), 4.1$3.9\left(\mathrm{~m}, 2 \mathrm{H}, \mathrm{C}^{\alpha} \mathrm{H}\right), 3.6-3.2\left(\mathrm{~m}, 12 \mathrm{H}, \mathrm{CH}_{2}\right), 2.9-2.7\left(\mathrm{~m}, 4 \mathrm{H}, \mathrm{C}^{\beta} \mathrm{H}_{2}\right), 1.7-1.2\left(\mathrm{~m}, 26 \mathrm{H}, \mathrm{CH}_{3}\right.$ [Boc] $\left.+\mathrm{C}^{\delta, \gamma} \mathrm{H}_{2}\right)$. IR 3297.0 (amide), 3021.0 and $2935.5(\mathrm{CH}$ arom. and alif), $1704.5(\mathrm{C}=\mathrm{O}$ anthraq.), 1684.4 (C=O amide), 1558,3, 1533.8, 1182.3. ((Elem. Anal. Calcd. for $\mathrm{C}_{70} \mathrm{H}_{80} \mathrm{~N}_{8} \mathrm{O}_{14}$ (1257.46g mol${ }^{-1}$ ): C, 66.86; H, 6.41; N, 8.91. Found: C, 66.44; H, 6.45; N, 8.97 (for the L isomer) and $\mathrm{C}, 66.66 ; \mathrm{H}, 6.37 ; \mathrm{N}, 8.93$ (for the $\mathrm{R}$ isomer). MS (ESI) Exact mass calcd $1257.4504 \mathrm{~g} / \mathrm{mol}$, found $\mathrm{m} / \mathrm{z} 1257.4506\left(\mathrm{MH}^{+}\right)$. MP $240-243^{\circ} \mathrm{C}$.

$L$ and $D$ 1,4-bis[2-( $N_{a}$-Lys)-aminoethylamino]-5,8-dihydroxyanthracene-9,10-dione (5) or L- and D- KAQ. To a magnetically stirred solution of $3(\sim 0.15 \mathrm{mmol}, \mathrm{L}$ or R isomer $)$ in DMF, minimal needed quantity, $\mathrm{NH}\left(\mathrm{CH}_{2} \mathrm{CH}_{3}\right)_{2}(3 \mathrm{ml})$ was added and the solution was stirred for 15 minutes. The solution was concentrated under reduced pressure to evaporate the DMF and the $\mathrm{NH}\left(\mathrm{CH}_{2} \mathrm{CH}_{3}\right)_{2}$ and the residue was washed, by suspending and centrifuging, few times with diethyl ether. The purity of the Fmoc-deprotected product was checked by TLC (toluene/AcOH/MeOH 70/29/1). The residue was dissolved in a 1:1 mixture of DMF: $\mathrm{CH}_{2} \mathrm{Cl}_{2}$ and $\mathrm{CF}_{3} \mathrm{COOH}(210 \mu \mathrm{L}, 1.5 \mathrm{mmol})$ was added. The solution was stirred 45 minutes at room temperature and evaporated under reduced pressure. The residue was washed with ether as described before, crystallized twice from EtOH/diethyl ether and essicated at $40^{\circ} \mathrm{C}$. Yield $78 \%$ (L isomer, L-KAQ) and 82\% (D isomer, D-KAQ). ${ }^{1} \mathrm{H}-\mathrm{NMR}$ in DMSO-d 6 : 13.6 (s, 2H, OH ), 10.6 (t, 2H, 6.1 Hz, NHarom.), 8.8 (t, 2H, 6.5 Hz, NH), 8.2-7.8 (broads, 12H, NH $), 7.7$ (s, 2H, Harom.), 7.2 (s, 2H, Harom.), 4.0-3.8 (m, 2H, $\left.\mathrm{C}^{\alpha} \mathrm{H}\right), 3.6-2.8\left(\mathrm{~m}, 14 \mathrm{H}, \mathrm{CH}_{2}+\mathrm{C}^{\varepsilon} \mathrm{H}_{2}+\mathrm{C}^{\beta} \mathrm{H}_{2}\right)$, 1.7$1.2\left(\mathrm{~m}, 8 \mathrm{H}, \mathrm{C}^{\delta, \gamma} \mathrm{H}_{2}\right)$. IR 3086.1 (amide), 3020.0 and $2955.6(\mathrm{CH}$ arom. and alif), $1704.7(\mathrm{C}=\mathrm{O}$ anthraq.), 1684.4 ( $\mathrm{C}=\mathrm{O}$ amide), 1212.4, 11132.1. Elem. Anal. Calcd. for $\mathrm{C}_{38} \mathrm{H}_{48} \mathrm{~F}_{12} \mathrm{~N}_{8} \mathrm{O}_{14}$ : $1068.8\left(\mathrm{~g} \mathrm{~mol}^{-1}\right)$; C 42.70, H 4.53, N 10.48. Found: C 42.55, H 4.43, N 10.27 (for the L-KAQ); C 42.47, H 4.48, N 10.41 (for the D-KAQ). MS (ESI) Exact mass calcd $612.7294 \mathrm{~g} / \mathrm{mol}$, found $\mathrm{m} / \mathrm{z}$ $612.7294\left(\mathrm{M}^{4+} * 4\right)$. MP $251^{\circ} \mathrm{C}$ decomposes.

$L$ and $D$ 1,4-bis[2-(Boc-Val)-aminoethylamino]-5,8-dihydroxyanthracene-9,10-dione (4). 1,4-bis[(2-aminoethyl)amino-5,8-dihydroxyanthracene-9,10-dione bis(trifluoroacetate) 1 $(0.200 \mathrm{~g}, 0.342 \mathrm{mmol})$ was dissolved in a mixture of dichloromethane $(55 \mathrm{~mL})$ and of DMF $(16 \mathrm{~mL})$. Then the solution was made sligthly alkaline with $\mathrm{N}\left(\mathrm{CH}_{2} \mathrm{CH}_{3}\right)_{3}$ to get the primary 
amines free for the subsequent reaction. L or D Boc-Val-OSu (0.820 g, $1.94 \mathrm{mmol}, 3$ equival.) was then added and the mixture was stirred 12 hours at room temperature, (TLC: toluene/acetone 70/30). The reaction mixture was poured in water and the organic layer was extracted three times with water to eliminate the DMF from the organic phase. The organic layer was then dried over sodium sulphate and evaporated to dryness under reduced pressure. The solid residue was then suspended in hexane and separated by centrifugation few times with to yield the desired products in $60 \%$ yield for the $\mathrm{L}$ isomer and $59 \%$ for the $\mathrm{R}$ isomer.

${ }^{1} \mathrm{H}-\mathrm{NMR}$ in DMSO-d 6 : 13.6 (s, 2H, OH), 10.6 (t, 2H, $6.2 \mathrm{~Hz}, \mathrm{NHarom}$ ), 8.2 (t, 2H, $6.4 \mathrm{~Hz}, \mathrm{NH}$ ), 7.7 (s, 2H, Harom.), 7.2 (s, 2H, Harom.), 6.7 (d, 2H, 6.4 Hz, NHBoc), 3.8 (m, 2H, C ${ }^{\alpha}$ ), 3.7-3.5 (m, 8H, $\left.\mathrm{CH}_{2}\right), 2.0-1.8\left(\mathrm{~m}, 2 \mathrm{H}, \mathrm{C}^{\beta} \mathrm{H}\right), 1.4(18 \mathrm{H}, \mathrm{Boc}), 0.8\left(\mathrm{~d}, 12 \mathrm{H}, 6.6 \mathrm{~Hz}, \mathrm{CH}_{3} \mathrm{Val}\right)$. ). IR 3437.6 (amide), 3020.9 and 2925.4 ( $\mathrm{CH}$ arom. and alif), $1707.1(\mathrm{C}=\mathrm{O}$ anthraq.), 1639.2 ( $\mathrm{C}=\mathrm{O}$ amide), 1609.1, 1558,9, 1192.3. Elem. Anal. Calcd. for $\mathrm{C}_{38} \mathrm{H}_{54} \mathrm{~N}_{6} \mathrm{O}_{10}\left(754,89 \mathrm{~g} \mathrm{~mol}^{-1}\right)$ : C, 60.46, H 7.21, N 11.13. Found: C, 61.16, H 7.31, N 11.27. (for the L isomer) and C, 60.77, H 7.27, N 11.09. (for the R isomer). MS (ESI) Exact mass calcd $754.8810 \mathrm{~g} / \mathrm{mol}$, found $\mathrm{m} / \mathrm{z} 755.8811 \mathrm{~g} / \mathrm{mol}$ $\left(\mathrm{MH}^{+}\right)$. MP $221^{\circ} \mathrm{C}$ decomposes.

$L$ and D 1,4-bis[2-Val-aminoethylamino]-5,8-dihydroxyanthracene-9,10-dione (4) or $L$ - and D- VAQ. To a magnetically stirred solution of $2(\sim 0.30 \mathrm{mmol}, \mathrm{L}$ or $\mathrm{R}$ isomer $)$ in $\mathrm{CH}_{2} \mathrm{Cl}_{2}$ $(20 \mathrm{~mL})$ was slowly added $\mathrm{CF}_{3} \mathrm{COOH}(1.15 \mathrm{~mL}, 1.5 \mathrm{mmol})$. The solution was stirred 45 minutes at room temperature, (TLC: toluene/acetone 70/30), and then evaporated under reduced pressure. The residue was washed twice by suspending it in diethyl ether and centrifuging it. Then, it was crystallized twice from EtOH/diethyl ether (TLC toluene/acetone/MeOH 70/28/2) and essicated at $40^{\circ} \mathrm{C}$. Yield $83 \%$ (L isomer, L-VAQ) and 74\% (D isomer, D-VAQ). ${ }^{1} \mathrm{H}-\mathrm{NMR}$ in DMSO-d $\mathrm{d}_{6}$ : 13.6 (s, 2H, OH), 10.6 (t, 2H, $6.3 \mathrm{~Hz}, \mathrm{NHarom}$ ), 8.8 (t, 2H, $6.3 \mathrm{~Hz}, \mathrm{NH}), 8.2\left(\mathrm{~s}, 6 \mathrm{H}, \mathrm{NH}_{3}{ }^{+}\right), 7.7$ (s, 2H, Harom.), 7.2 (s, 2H, H arom.), 4.0-3.0 (m, 10H, $\mathrm{C}^{\alpha} \mathrm{H}$ and $\left.\mathrm{CH}_{2}\right), 2.11 .9\left(\mathrm{~m}, 2 \mathrm{H}, \mathrm{C}^{\beta} \mathrm{H}\right.$ ), 0.8 (d, 12H, 6.5 Hz, $\mathrm{CH}_{3}$ Val). IR 3427.7 (amide), 3018.6 and 2955.6 (CH arom. and alif), 1702.1 ( $\mathrm{C}=\mathrm{O}$ anthraq. $), 1679.3 \quad(\mathrm{C}=\mathrm{O}$ amide $), 1609.1,1553,9$, 1207.3. Elem. Anal. Calcd. for $\mathrm{C}_{32} \mathrm{H}_{36} \mathrm{~F}_{6} \mathrm{~N}_{6} \mathrm{O}_{10}$ : $778.67\left(\mathrm{~g} \mathrm{~mol}^{-1}\right)$; C 49.36, H 4.66, N 10.79. Found: C 49.11, H 4.56, N 10.83 (for the L-VAQ); C 48.94, H 4.59, N 10.81 (for the D-VAQ). MS (ESI) Exact mass calcd $600.6744 \mathrm{~g} / \mathrm{mol}$, found $\mathrm{m} / \mathrm{z} 600.6738\left(\mathrm{M}^{4+} * 4\right)$; g/mol. MP $248^{\circ} \mathrm{C}$. decomposes

DNA binding studies. Spectroscopic titrations were performed with a Perkin-Elmer Lambda 20 spectrophotometer. Measurements were carried out at $25^{\circ} \mathrm{C}$ in ETN buffer at different ionic strengths. Binding was followed in the ligand absorption region upon addition of increasing amounts of DNA to a freshly prepared drug solution. To avoid large systematic inaccuracies due to experimental errors in extinction coefficients, the range of bound drug fractions analyzed was 0.15-0.85. Data were evaluated according to the equation of McGhee \& Von Hippel for noncooperative ligand-lattice interactions ${ }^{31}$ :

$\mathrm{r} / \mathrm{m}=\mathrm{K}_{\mathrm{i}}(1-\mathrm{nr})^{\mathrm{n}} /[1-(\mathrm{n}-1) \mathrm{r}]^{\mathrm{n}-1}$

where $r$ is the molar ratio of bound ligand to DNA, $m$ is the free ligand concentration, $K_{i}$ the intrinsic binding constant, and $\mathrm{n}$ the exclusion parameter.

Topoisomerase II assay. Plasmid pBR 322 was first linearized with the restriction enzyme Eco 
RI at the conditions recommended by the supplier and then 3'-labelled with Klenow fragment of DNA Polymerase I. After phenol-chloroform extraction and ethanol precipitation, DNA was digested with the second restriction enzyme, Hind III. The uniquely 3'-end-labeled DNA fragments then purified on a microspin G-25 column (Pharmacia Biotech, USA) and used without further purification.

For topoisomerase II reaction, in a total volume of $20 \mu \mathrm{L}, 50 \mathrm{ng}$ of 3'-labeled DNA were incubated for $30 \mathrm{~min}$ at $37^{\circ} \mathrm{C}$ with $1.2 \mathrm{U}$ of topoisomerase II in the absence or presence of increasing drug concentrations in $50 \mathrm{mM}$ TRIS-HCl, $\mathrm{pH} 8.0,120 \mathrm{mM} \mathrm{KCl}, 10 \mathrm{mM} \mathrm{MgCl}$, $0.5 \mathrm{mM}$ ATP, $0.5 \mathrm{mM}$ DTT and $30 \mu \mathrm{g} / \mathrm{mL}$ BSA. Reaction was stopped by adding $5 \mu \mathrm{L}$ of stop mixture (5\% SDS, $2.5 \mathrm{mg} / \mathrm{ml}$ proteinase $\mathrm{K}, 5 \mathrm{ng}$ cold DNA) and incubating for $90 \mathrm{~min}$ at $50^{\circ} \mathrm{C}$. The reaction products were then loaded onto $1 \%$ agarose gel in TBE and run at low voltage overnight. Gels were transferred to Whatman $3 \mathrm{MM}$ paper, dried under vacuum at $50^{\circ} \mathrm{C}$ and autoradiographed (Amersham Hyperfilm MP).

Cell line and cytotoxyc assay. HL60 cells were cultured in RPMI-1640 medium (Flow laboratories, Irvine, UK) plus 10\% fetal calf serum. Drug treatments were carried out for $1 \mathrm{~h}$ at $37^{\circ} \mathrm{C}$ on exponentially growing cells. In cytotoxic experiments cell survival was determined using the MTT assay. Cells were centrifuged after drug treatment, washed, resuspended and cultured in drug-free medium for $96 \mathrm{~h}$.

\section{Acknowledgements}

The authors are indebted to AIRC, Associazione Italiana per la Ricerca sul Cancro, for financial support.

\section{References}

1. Workman, P. Cancer Chemother. Pharmacol. 2003, 52, Suppl 1, S45.

2. de Bono, J. S.; Tolcher, A. W.; Rowinsky, E. K. Breast Cancer Res. 2003, 5, 154.

3. Watters, J. W.; McLeod, H. L. Biochim. Biophys. Acta 2003, 1603, 99.

4. Denny, W. A. Curr. Med. Chem. 2001, 8, 533.

5. Goodsell, D. S. Curr. Med. Chem. 2001, 8, 509.

6. Wemmer, D. E. Biopolymers 1999-2000, 52, 197.

7. James, P. L.; Brown, T.; Fox, K. R. Nucleic Acids Res. 2003, 31, 5598.

8. Cassidy, R. A.; Puri, N.; Miller, P. S. Nucleic Acids Res. 2003, 31, 4099.

9. Sukhanova, A.; Grokhovsky, S.; Zhuze, A.; Devy, J.; Pluot, M.; Oleinikov, V.; Nabiev, I. Anticancer Res. 2003, 23, 2609.

10. Arimondo, P. B.; Bailly, C.; Boutorine, A.; Sun, J. S.; Garestier, T.; Helene, C. C. R. Acad. Sci. III 1999, 322, 785. 
11. Arimondo, P. B.; Helene, C. Curr. Med. Chem. Anti-Canc. Agents 2001, 1, 219.

12. Gatto, B.; Zagotto, G.; Sissi, C.; Cera, C.; Uriarte, E.; Palu', G.; Capranico G.; Palumbo, M. J. Med. Chem. 1996, 39, 3114.

13. Gatto, B.; Zagotto, G.; Sissi, C.; Palumbo, M. Int. J. Biol. Macromol. 1997, 21, 319.

14. Thomas, X.; Archimbaud, E. Hematology and Cell Therapy 1997, 39, 63.

15. Cummings, J.; Macpherson, J. S.; Meikle, I.; Smyth, J. F. Biochem. Pharmacol. 1996, 52, 979.

16. Cummings, J.; Hadfield, J. A.; Meikle, I.; McGown, A. T.; Smyth, J. F. Anticancer Drugs 1996, 7, 636.

17. Meikle, I.; Cummings, J.; Macpherson, J. S.; Smyth, J. F. Br. J. Cancer 1996, 74, 374.

18. Meikle, I.; Cummings, J.; Macpherson, J. S.; Hadfield, J. A.; Smyth, J. F. Biochem. Pharmacol. 1995, 49, 1747.

19. Meikle, I.; Cummings, J.; Macpherson, J. S.; Smyth, J. F. Anticancer Drug Des. 1995, 10, 515.

20. Pohle, W.; Bohl, M.; Flemming, J.; Bohlig, H. Biophys. Chem. 1990, 35, 213.

21. Zagotto, G.; Mitaritonna, G.; Sissi C.; Palumbo, M. Nucleosides, Nucleotides and Nucleic Acids 1998, 17, 2135.

22. Zagotto, G.; Supino, R.; Favini, E.; Moro, S.; Palumbo, M. Farmaco 2000, 55, 1.

23. Kharasch, E. D.; Novak, R. F. Arch. Biochem. Biophys. 1984, 234, 497.

24. Cheng, C. C.; Zee Cheng, R. K. Prog. Med. Chem. 1983, 2083.

25. Zee Cheng, R. K.; Mathew, A. E.; Xu, P. L.; Northcutt, R. V.; Cheng, C. C. J. Med. Chem. 1987, 30, 682.

26. Lown, J. W.; Morgan, A. R.; Yen, S. F.; Wang, Y. H.; Wilson, W. D. Biochemistry 1985, 16, 4028.

27. Chen, K. X.; Gresh, N.; Pullman, B. Nucleic Acids Res. 1986, 14, 3799.

28. Lavery, R.; Pullman, B.; Zakrzewska, K. Biophys. Chem. 1982, 15, 343.

29. Wells, R. D.; Larson, J. E.; Grant, R. C.; Shortle, B. E.; Cantor, C. R. J. Mol. Biol. 1970, 54, 465.

30. Grant, R. C.; Harwood, S. J.; Wells, R. D. J. Am. Chem. Soc. 1968, 90, 4474.

31. McGhee, J. D.; Von Hippel, P. H. J. Mol. Biol. 1974, 86, 469. 